\title{
Correlation between Two Parameters of Mice Behaviour in the Open Field Test
}

\author{
Nikola M. Stojanović1, Pavle J. Randjelović2 ${ }^{2}$ Niko S. Radulović ${ }^{3}$ \\ ${ }^{1}$ University of Niš, Faculty of Medicine, Niš, Serbia \\ ${ }^{2}$ University of Niš, Faculty of Medicine, Department of Physiology, Niš, Serbia \\ ${ }^{3}$ University of Niš, Faculty of Science and Mathematics, Department of Chemistry, Niš, Serbia
}

\section{SUMMARY}

The open field test is being used extensively for the determination of different aspects of animal behaviour for over seventy years. The correlation between different behavioural parameters obtained in this test, although previously studied, is still debatable. Thus, we aimed to analyze and correlate behaviour scores to estimate the importance of individual parameters in this type of experiment. The open field test was performed on male BALB/c mice treated with either saline $(10 \mathrm{ml} / \mathrm{kg})$ or diazepam $(2$ $\mathrm{mg} / \mathrm{kg}$ ), one hour before the experiment. The behaviour scores (number of squares crossed and rearings performed) obtained either by video recording or direct observation, during a five-minute experiment, were compared using a t-test and were tested for correlation. As expected, diazepam caused an increase in the number of squares crossed and rearings performed by the animals. The number of rearings was statistically different between the groups monitored in two different ways. The correlations between the behaviour scores obtained in the two modes of monitoring for all groups were moderate/strong positive ones. The correlation analyses revealed that the amount of information conveyed by a single behaviour parameter, either the number of squares crossed or the number of rearings, could be sufficient to estimate the animals' motor activity in the open field test. Also, the results of this test could provide clues to very important piece of information in drug discovery, i.e. the general animal behaviour under the influence of CNS acting drugs in an experiment.

Key words: open field test, behaviour score, correlation, diazepam

Corresponding author:

Nikola M. Stojanović

E-mail: nikola.st90@yahoo.com 
The term "open field" (OF) is used to designate an enclosed, most often square, rectangular, or circular in shape space with walls surrounding it that prevents escape. The open field test (OFT) was designed and introduced by Hall during 1930's (1-3) using rats as animals of choice. Nowadays, OFT is frequently used to access anxiety behaviour in rodents, considered to be observable during the test, which might be a consequence of agoraphobia and individual animal testing. Characteristic thigmotaxis, i.e. spontaneous preference for peripheral parts of the OF apparatus, with marked reduction in ambulation, is shown by rodents in these situations (4). Sadly, the mechanisms by which animals (i.e. rodents) perceive the OF are still not clarified (5).

Animal movements expressed by the number of squares crossed and the numbers of rearings are the common behaviour parameters noted during OFT. One can expand the panel of tracked parameters with: the time spent moving and/or sniffing, exploration latency, change in activity overtime, time spent in the centre, defecation, urination, vocalization and teeth chattering (6). However, it is considered that the number of squares crossed and rearings performed reflect and adequately correlate with the animal hippocampal theta activity (6). Some of these parameters are more or less conclusive depending on the desired test output. During certain types of experiments, e.g. the application of different drugs, animal genetic manipulations, etc., OFT on its own might not be an adequate choice, since the motor output could be influenced by interfering variables such as: freezing (or other fear-related behaviour), sickness and circadian cycle, etc. (7). Thus, some authors put forward arguments against the use of OFT (7).

The correlation between the parameters commonly noted in the OFT was previously studied; however, no clear and precise conclusions were made (6). The aim of this work was to analyze and correlate the two most commonly recorded behaviour scores obtained from animals treated with saline/diazepam in the OFT. The number of squares crossed and rearings performed would be evaluated for mutual correlation in order to estimate the importance of individual parameters traced in this type of experiment. Additionally, the comparison of scores obtained by video recording and direct observation of animal behaviour will be performed and discussed.

Disease and pathogen free male BALB/c mice (34 months old, weighting from 20-25 g), obtained from the animal facilities of the Institute of Biomedical Research, Faculty of Medicine, University of Niš (Niš, Serbia), were randomly grouped and used in this study. Animals were housed under standard laboratory conditions at $22 \pm 2{ }^{\circ} \mathrm{C}$ and $60 \%$ air humidity, with 12-h light/dark cycles (lights were switched on at 7:00 a.m.). Before the experiments, all animals had free access to food and water. One week prior to the experiments, the animals were grouped (68 animals per group) and housed together. The experiments were performed in accordance with the declaration of Helsinki and European Community guidelines for the ethical handling of laboratory animals (EU Directive of 2010; 2010/63/EU) and the related ethics regulations of the Republic of Serbia.

The OF apparatus was a square box, made of clear Plexiglas ${ }^{\circledR}$ (Evonik Industries AG, Essen, Germany) and measuring $50 \times 50 \times 35 \mathrm{~cm}$ with lines drawn on the floor of the box dividing it into 25 equal squares $(10 \times 10 \mathrm{~cm})(8)$. One hour before the treatment, the animals were transferred to the lab and left for acclimatization. Animals treatment included: $0.9 \%$ $(\mathrm{w} / \mathrm{v})$ aqueous $\mathrm{NaCl}$ - saline (vehicle, $10 \mathrm{ml} / \mathrm{kg}$ e.d. 0.2 $0.25 \mathrm{ml} / \mathrm{animal})$ and diazepam $(2 \mathrm{mg} / \mathrm{kg}$ in a volume of $0.1 \mathrm{ml} /$ animal, Hemofarm, Vršac, Serbia). One hour after the intraperitoneal application of substances, mice were placed individually into a corner of the arena and allowed to explore it freely for the next five minutes. After each session, the OF apparatus was cleaned with $10 \%$ ethanol (v/v) and then dried. The experiments were performed in the period from 8:00 to 11:00 a.m. (during the light cycle) at the Institute for Biomedical Research at the Faculty of Medicine, under the same ambient parameters.

Two sets of experiments were, with 6-8 mice per group, conducted in order to obtain behaviour scores that included the frequency of ambulation (the number of crossed sector lines with all four paws) and rearing (the number of times mice stood on their hind limbs 
where the body formed an angle with the floor greater than $45^{\circ}$ ). Behaviour scores were monitored by a researcher (male) unaware of the animal treatment. He was standing $50 \mathrm{~cm}$ from the $\mathrm{OF}$ apparatus equipped with a stopwatch and a counter. The animal activity was also recorded using an overhead camera (Canon EOS 650D). The videos were subsequently analyzed, by trained researchers, when the mentioned behaviour scores were noted. After the completion of the study, animals were returned to their home cages and reused in other experiment.

The results were expressed as the mean $\pm \mathrm{SD}$. Statistically significant differences between the groups of animals treated with the same substance, where the behaviour scores were obtained by direct observation or video recording, were determined by Student's t-test (Graphpad Prism version 5.03, San Diego, CA, USA). Probability values $(\mathrm{p})$ less than 0.05 were considered to be statistically significant. Additionally, the behaviour scores (the number of squares crossed and rearings performed), in both groups, noted by direct researcher observation or from camera recordings were tested for correlation. The magnitudes of Pearson's correlation coefficients were treated as follows: very weak (0.0$0.19)$, weak (0.2-0.39), moderate (0.4-0.59), strong (0.6$0.79)$ and very strong $(>0.8)(9)$.

Following the application of diazepam, an increase in the number of squares crossed and rearings was observed either by direct observation or by the analysis of the camera recordings (Figure 1A and B). There was no statistically significant difference between these two types of observation when the number of squares crossed was compared. Similarly, for the same behaviour parameter, no statistically significant difference was found for the animals treated with saline (Figure 1A). On the other hand, the number of rearings, in both saline and diazepam-treated groups, was statistically significantly different for the two observation modes (Figure 1B).
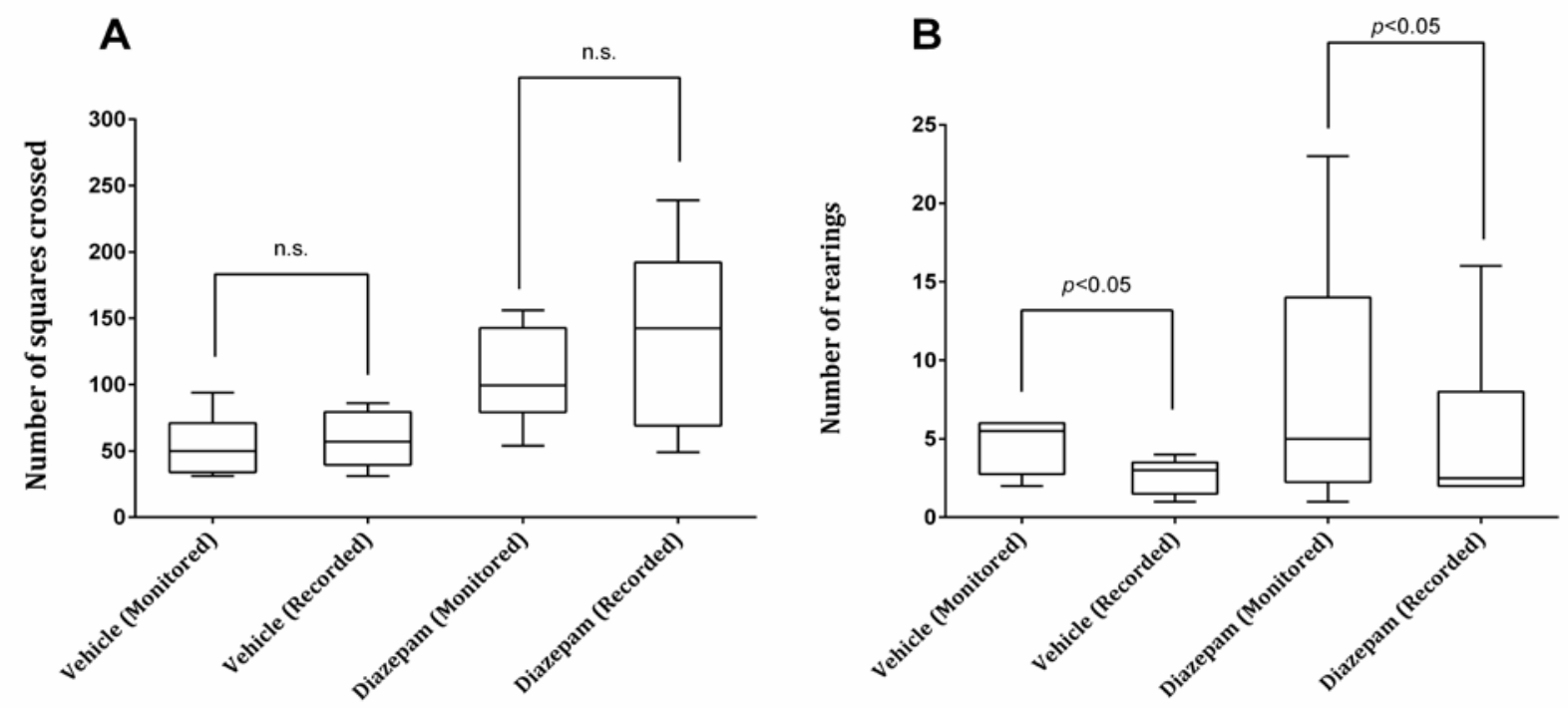

Figure 1. Comparison between the number of squares crossed (A) and rearings performed (B) by animals treated with saline or diazepam; n.s. - no statistically significant difference 
The correlation data (correlation coefficient, p-value and the magnitude of correlation) for the behaviour scores (i.e. the correlation between the number of squares crossed and the number of rearings within one mode of observation) obtained for all groups (vehicle and diazepam - direct observation and video recorded) during the OFT are presented in Table 1. Moderate and strong positive correlation magnitudes were noted. The highest correlation coefficient value (R2) was found between the behaviour scores obtained from the diazepam-treated groups.

The lack of correspondence between the results (the behaviour scores in animals) of the two methods of observation, direct and video recording, was established for the number of rearings (Figure 1B).
This parameter is quite variable and somewhat hard to measure, thus one may say that this result might have been expected. Namely, during direct monitoring of animal behaviour, the researcher has a time window lasting only a few seconds while the animal is performing the rearing to observe and record this specific movement. On the other hand, the video-recorded five-minute session of the animal behaviour during OFT is significantly easier to analyze (there is a possibility of rewinding, if needed). Additionally, the recorded time interval allows for a large number of other possible parameters to be analyzed (the number of central square entries, the number of defecations, grooming behaviour, etc.) without the use of specific software.

Table 1. Correlation between the number of squares crossed and rearings performed in the OFT in animals treated with vehicle (saline, $10 \mathrm{ml} / \mathrm{kg}$ ) and diazepam $(2 \mathrm{mg} / \mathrm{kg}$ )

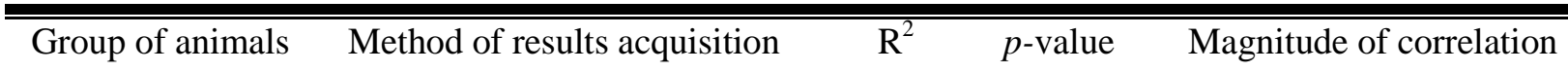

\begin{tabular}{ccccc}
\hline \multirow{2}{*}{ Vehicle } & Direct observation & 0.661 & 0.0040 & Strong \\
& & & & Strong \\
& Video recording & 0.601 & 0.0701 & \\
\hline \multirow{2}{*}{ Diazepam } & Direct observation & 0.502 & 0.0098 & Moderate \\
& & & & Strong \\
& Video recording & 0.786 & 0.0033 & \\
\hline \hline
\end{tabular}

The correlations between the measured behaviour parameters (between the number of squares crossed and rearings performed) proved to be positive, mostly strong and moderate (Table 1). The highest R2 was observed within the group of animals treated with diazepam when the behaviour of the mice was video recorded. Also, this correlation was found to be statistically significant $(p=0.0033)$. This high correlation magnitude could be partially explained by the effect of diazepam, i.e. due to the consequence of brain GABA neurotransmission changes (10). The correlation between the parameters of the OFT were previously studied and it was shown that different variables mutually significantly correlate, both positively and negatively (6).

Diazepam, a standard anxiolytic drug, in a dose of $2 \mathrm{mg} / \mathrm{kg}$ used in this study, demonstrated an increase in animal behaviour scores (Figure $1 \mathrm{~A}$ and $\mathrm{B}$ ). The described behaviour could be interpreted as an increase in animal activity that is due to a decrease in anxiety, originating from unfamiliar and spacious surroundings, and frizz behaviour. In the OFT, higher doses of diazepam, $\geq 10 \mathrm{mg} / \mathrm{kg}$, are known to cause a reduction in animal activity that is a consequence of both central and 
peripheral neuromuscular blockade (10). Diazepam displayed anxiolytic effect $(8,11-12)$ in BALB/c mice, both male and female, treated with the low dose (2 $\mathrm{mg} / \mathrm{kg}$ ) of this drug.

The OFT is a useful method that allows an insight into animal behaviour within a novel environment. Initially designed as a method for monitoring rat "emotionality" (1-3), during the years the test gained the form of a method for the estimation of motor activity (movement); it is considered that the animals that explore the central region of the $\mathrm{OF}$ apparatus are less fearful (i.e. less 'anxious')(5, 7). However, during the past decade, due to a large increase in OFT exploitation, some concerns were raised about its validity (7).

Since the OFT is based on the tracking of animal behaviour within new surroundings, there are numerous factors that can affect the final outcome of the test (false positive/negative results). Some of the possible external factors include animal housing ambient parameters, examination room noise, temperature, illumination, etc. Besides a number of external influences on the behaviour score in the OFT, the animal strain can be a major issue as well. It is well documented that the $\mathrm{BALB} / \mathrm{C}$ and $\mathrm{A} / \mathrm{J}$ mice are resistant to D-amphetamine and do not display hyperlocomotion after its application (13).

\section{CONCLUSIONS}

We can highlight that the OFT, although possessing certain downsides, is still a useful method for the estimation of animal movement impair caused by the application of a substance affecting CNS function and/or muscle tone. Although there are some interlaboratory concerns about the reproducibility/correlation of results obtained from the open field test, the authors' attitude on this issue is different. The results of this test could provide clues to very important piece of information in drug discovery, i.e. the general animal behaviour under the influence of CNS acting drugs in an experiment.

\section{Acknowledgment}

This publication is a part of Nikola $M$. Stojanović's PhD thesis, under the supervision of Pavle J. Randjelović. This work was supported by the Ministry of Education, Science and Technological Development of the Republic of Serbia (Project No. 172061). 


\section{References}

1. Hall C, Ballachey EL. A study of the rat's behavior in a field: a contribution to method in comparative psychology. U CalifPsychol 1932; 6: 1-12.

2. Hall C. Drive and emotionality: factors associated with adjustment in the rat. J Comp Psychol 1934; 27: 89-108. https://doi.org/10.1037/h0073676

3. Hall CS. Emotional behavior in the rat. II. The relationship between need and emotionality. J Comp Psychol 1936; 22: 61-8. https://doi.org/10.1037/h0055711

4. Bhattacharya SK, Satyan KS. Experimental methods for evaluation of psychotropic agents in rodents: I-antianxiety agents. Indian J Exp Biol 1997; 35: 565-75.

5. Lamprea MR, Cardenas FP, Setem J, Morato S. Thigmotactic responses in an open-field. Braz J Med Biol Res 2008; 41: 135-40. https://doi.org/10.1590/S0100-879X2008000200010

6. Walsh RN, Cummins RA. The open-field test: A critical review. Psychol Bull 1976; 83:482-504. https://doi.org/10.1037/0033-2909.83.3.482

7. Stanford SC. The Open Field Test: reinventing the wheel. J Psychopharmacol 2007; 21: 34-135. https://doi.org/10.1177/0269881107073199

8. Radulović NS, Miltojević AB, Randjelović PJ, et al. Effects of methyl and isopropyl N- methylanthranilates from ChoisyaternataKunth (Rutaceae) on experimental anxiety and depression in mice. Phytother Res 2013; 27: 1334-8.

https://doi.org/10.1002/ptr.4877

9. Evans JD. Straight forward statistics for the behavioral sciences. Brooks/Cole Pub. Co., Pacific Grove Pacific Grove, 1996: 600.

10. Crestani F, Löw K, Keist R, et al. Molecular targets for the myorelaxant action of diazepam. Mol Pharmaco 2001; 159: 442-5. https://doi.org/10.1124/mol.59.3.442

11. Pejović A, Denić MS, Stevanović D, et al. Discovery of anxiolytic 2-ferrocenyl-1,3thiazolidin-4-ones exerting GABAA receptor interaction via the benzodiazepine-binding site. Eur J Med Chem 2014; 83: 57-73. https://doi.org/10.1016/j.ejmech.2014.05.062

12. Radulović NS, Dekić MS, Randjelović PJ, et al. Toxic essential oils: Anxiolytic, antinociceptive and antimicrobial properties of the yarrow Achillea umbellate Sibth. et Sm. (Asteraceae) volatiles. Food ChemToxicol 2012; 50: 2016-26. https://doi.org/10.1016/j.fct.2012.03.047

13. Gould TD, O'Donnell KC, Picchini AM, Manji HK. Strain differences in lithium attenuation of d-amphetamine-induced hyperlocomotion: a mouse model for the genetics of clinical response to lithium. Neuropsychopharmacol 2007; 32:1321-33

https://doi.org/10.1038/sj.npp.1301254 


\title{
Korelacija između dva bihevioralna parametra kod miševa u „open field" testu: poređenje rezultata dobijenih direktnim posmatranjem i snimanjem kamerom
}

\author{
Nikola M. Stojanović1 ${ }^{*}$, Pavle J. Ranđelović2 ${ }^{2}$ Niko S. Radulović ${ }^{3}$ \\ ${ }^{1}$ Univerzitet u Nišu, Medicinski fakultet, Niš, Srbija \\ ${ }^{2}$ Univerzitet u Nišu, Institut za fiziologiju, Medicinski fakultet, Niš, Srbija \\ ${ }^{3}$ Univerzitet u Nišu, Departman za hemiju, Prirodno-matematički fakultet, Niš, Srbija
}

\begin{abstract}
SAŽETAK
"Open field" test se intenzivno koristi preko sedamdeset godina za procenu različitih aspekata ponašanja laboratorijskih životinja. Iako postoje publikacije koje razmatraju korelaciju između različitih parametara ponašanja životinja dobijenih u ovom testu, njihovi rezultati su još uvek nejasni. Iz ovih razloga, za cilj ove studije je postavljena analiza i međusobna korelacija parametara ponašanja životinja da bi se utvrdio značaj pojedinačnih parametara koji se mogu pratiti u ovom testu. U ovom radu, u „open field" testu, korišćeni su miševi muškog pola, soja BALB/c, koji su tretirani fiziološkim rastvorom (rastvor $\mathrm{NaCl}, 10 \mathrm{ml} / \mathrm{kg}$ ) ili dijazepamom $(2 \mathrm{mg} / \mathrm{kg}$ ) jedan sat pre početka eksperimenta. Bihevioralni skor (broj pređenih kvadrata i broj vertikalnih pokreta (rearings)) dobijen u testu, bilo snimanjem ili direktnim posmatranjem, tokom petominutnog trajanja testa, upoređivan je t-testom $\mathbf{i}$ ispitano je postojanje korelacije među njima. Kao što je očekivano, aplikacija dijazepama je izazvala povećanje broja kvadrata koje je životinja prešla i broja vertikalnih pokreta. Nađeno je da se broj vertikalnih pokreta statistički značajno razlikovao kada je ovaj parameter određivan direktnim posmatranjem, odnosno snimanjem. Utvrđene su umerene i jake korelacije između bihevioralnih parametara. Korelaciona analiza je pokazala da se isti podaci mogu dobiti i iz samo jednog od ova dva bihevioralna parametra, a koji se odnose na procenu motorne aktivnosti životinja u „open field" testu. Takođe, rezultati ovog testa daju važan uvid u generalno ponašanje životinja pod uticajem lekova koji deluju na CNS.
\end{abstract}

Ključne reči: : „open field" test, bihevioralni skor, korelacija, dijazepam 